\title{
IS JOURNALING EMPOWERING? STUDENTS' PERCEPTIONS OF THEIR REFLECTIVE WRITING EXPERIENCE
}

\author{
M Harris \\ Department of Post Graduate Nursing Studies, Durban Institute of Technology \\ Corresponding author: maureenh@dit.ac.za
}

Keywords: reflective journals; empowerment; critical reflective practice; critical thinking; reflection

\begin{abstract}
South African health care organisations are faced by enormous challenges. Responsive measures must include employing nurse practitioners who can think critically and creatively and who can make appropriate decisions that do not necessarily fit into theory learned within a formal educational system. This study arose out of the need for a university of technology nursing department to respond to limitations imposed by traditionally-formed educational frames of reference of post-basic nurse practitioner students that historically rated proficiency in the tasks of nursing above that of knowing nursing. Reflective journals were introduced as an educational strategy within a model for critical reflective practice (Van Aswegen, 1998) to promote independent thinking for improved professional practice and support and sustain 'deep'learning. This four-year qualitative descriptive study, using content analysis of 110 student journal self-evaluations, seeks to determine the value part-time post-basic nursing students place on journaling as a means of enhancing critical reflective practice. The findings of the study suggest that open-ended reflective journals encouraged self-directed learning. Despite journaling being perceived as an arduous, time-consuming exercise particularly in the light of concomitant learning, occupational and social commitments, it was seen as a means of promoting self-insight and self-development and as a viable strategy for life-long learning.
\end{abstract}

\section{OPSOMMING}

'n Opvoedkundige program vir Suid-Afrikaanse verpleegkundiges van verskillende kulture, gebaseer op 'n model vir kritiese ondersoek van taakverrigting (Van Aswegen, 1998), het tot hierdie navorsing aanleiding gegee. Hierdie kwalitatiewe beskrywende navorsing poog om te bepaal hoe belangrik na-basiese verpleegkundiges die bydrae van verslagdoening tot die verbetering van die kritiese ondersoek van taakverrigting ag. Hierdie studie het ontstaan vanweë die behoefte van 'n departement van verpleegkunde aan 'n universiteit van tegnologie om op die beperkinge van nabasiese verpleegkundige studente se opvoedkundige navorsingsraamwerke te reageer. Voorheen het hierdie studente bekwaamheid in die take van verpleging hoër as kennis van verpleging geag. Reflektiewe joernale is bekendgestel as 'n opvoedkundige strategie binne 'n model vir kritiese reflektiewe praktyk (Van Aswegen, 1998) om onafhanklike denke vir verbeterde professionele praktyk te bevorder en om "diep" leer te ondersteun en vol te hou. In hierdie kwalitatiewe beskrywende studie wat vier jaar geduur het is die inhoudsanalise van die selfevaluerings van 110 joernale van studente bestudeer. Daar is gepoog om die waarde te bepaal wat deeltydse nabasiese studente in Verpleegkunde op die skryf van 'n joernaal plaas. Dit is gedoen met die oog op die bevordering van kritiese reflektiewe praktyk. Die navorsing het bevind dat oop-einde-reflektiewe joernale selfgerigte leer bevorder het. Die skryf van 'n joernaal is beskou as 'n moeilike, tydrowende en lang proses wat hoë eise aan studente gestel het in die lig van werk- en sosiale verpligtinge. Desnieteenstaande is dit gesien as 'n wyse om selfinsig en selfontwikkeling te bevorder en as 'n moontlike strategie vir lewenslange leer. 


\section{INTRODUCTION}

Critical reflective practice is seen as a means of empowering practitioners and leading to more autonomous practice (Van Aswegen, 1998; Owens, Francis \& Tollefson, 1998). In effect, it is the ability of practitioners to both literally and figuratively step back from their own practice and think about what they are doing in light of what they think or believe or know they ought to be doing. This thinking or believing or knowing is supported by reason, experience, evidence, analysis and logic. The value in this approach lies in the recognition that many situations are both complex and problematic, for which there is no simple or single solution but through making explicit that which is implicit, it enables the practitioner to focus on decisions that will improve practice. Reflective journaling is a medium which supports this process.

This paper is about nursing students' thoughts on their journey of self-discovery through reflective journaling.

In most health systems the infrastructure and systems control nursing practice, but even in these well-regulated systems, the operationalisation of the health services is dependent on critical reflective practitioners. The South African health system is faced with enormous challenges and increasingly affected by an exodus of both nursing and medical staff (Lehmann \& Sanders, 2002). It is therefore essential that nurses who work in the services are able to meet with the additional demands of reduced staff and greater responsibilities, if disorder is to be averted. In addition, massification of education for South Africans is a strategy clearly identified by the African National Congress (ANC) government as part of the transformation process towards a more accessible, equitable and effective educational system (Norris, 2001). This strategy comes at a time when there is a decline in student numbers in higher education institutions (HEl), spiraling costs, increased global competition, shrinking resources and cuts in student subsidy (Nkopodi, 2002). This is compounded by the increasing awareness of students and employing bodies of limitations inherent in curricula of higher education institutions that are too contentbased, prescriptive, outmoded, ungrounded and delivered in inaccessible formats and time frames (Johnson, in Chabeli, 2002:5). Efforts to maximise educator resources have resulted in increased student- educator ratios and reduced individual student contact. The effectiveness of traditional didactic teaching is under question and it is essential that HEls explore new avenues for student learning. This squeeze on the HEls is further exacerbated by the difficulties faced by the employing bodies in the health sector. Many public service organisations, especially health services, do not have the capacity to release their workforce on a full time learning basis (Chapman \& Howkins, 2003; Gwele, 2003). It is becoming increasingly difficult for working nurses to engage in further studies for the purposes of upgrading their qualifications and increasing their skills and knowledge base. As a result, there is a strong move away from the traditional transmission approach in contact teaching sessions to independent, learner-centered techniques, especially for adult learners in higher education.

This study arose out of the need for a South African university of technology nursing department to respond to the limitations imposed by the educational frames of reference of post-basic nurse practitioner students. Many of these students originated from the more traditional educational backgrounds that historically rated the proficiency of the nursing tasks above that of nursing knowledge (Radebe, 2001). Also, for many students, nursing is perceived essentially as a clinically based profession where writing skills are not highly rated or practiced. The post-basic nursing students in these nursing programmes have limited class contact sessions of approximately 32 days within the academic year. Therefore how to engage them in the learning process in a meaningful, continuous way was a concern for the teaching staff.

In view of the above, reservations are expressed about the effectiveness of traditional approaches to teaching in enabling "deep" or emancipatory learning. The situation calls for the shaping of nurses as critical reflective practitioners.

As a nurse educator and researcher, I took these factors into account while developing a post-basic nursing management course, founded upon Van Aswegen's 1998 model for critical reflective practice, a key precept of which is transformatory learning.

As an educator, I became the travel guide, walking along side the students as they embarked on their journeys 
of self-discovery by providing the maps and the directions for the road upon which the students walked and left their imprints. Their unique explorations were recorded in their reflective journals. It takes great courage for students to embark on this journey, to trust both their travel and inner guides, and follow the unseen path ahead.

This paper reflects the students' perceptions of the value they placed on their experiences and lessons learned through journaling.

\section{THEORETICAL UNDERPINNING}

The theoretical underpinning is broadly based on concepts contained in Van Aswegen's 1998 model of critical reflective practice, as well as through the literature and the insights that have emerged out of this study, specifically the students' thoughts on the value of journaling.

Nurse empowerment: Critical social theory draws on the works of Paolo Freire and Habermas and is forged by Marxist and Hegelian philosophy. The essential tenets of empowerment focus on the emancipation of the underprivileged or the oppressed. Lack of power is associated with negative, authoritarian, patriarchal systems of power, with the ability to control people's behaviour, lives and economic resources. This concept of power is closely linked with status and is rooted in the notion that certain groups, in this case, nurses, are in a subordinate position (Kuokkanen \& Leino-Kilpi, 2000). But while my research (and practice) is broadly aligned with the emancipatory and critical tradition, as outlined by Carr and Kemmis (1986), for example, where power is acknowledged and problematised, it has taken place in small, incremental stages over time, awareness awakening and developing with student engagement, resulting in my attempts to create a safe milieu where power can be reflected upon critically. This does not mean that as an educator, I consciously introduce what Ellsworth (1992) calls prescriptions of empowerment. These comprise key concepts '"empowerment', 'student voice', 'dialogue' or even the term 'critical'” derived from critical literature. She argues that the interpretation of these concepts has been so distorted that they have become repressive myths exacerbating domination of one person by another, the effect of which results in her question "What diversity do we silence in the name of "liberatory" pedagogy?"

Although the process of the reflective journal includes a writer and a reader-responder, it is not clear who occupies the term 'student' or 'teacher' in the process as power is intentionally delimited through the introduction of the self-evaluation concept and the negotiated rules of engagement where students' narratives are acknowledged as their 'truth' guiding me, the readerresponder, through their realities. Instead, the intention of Van Aswegen's critical reflective practice model (1998) is to use learning to empower nurses, highlighting growth, development and a growing sense of control over their own individual lives and actions. Empowerment is a process of increasing learners' access to independent thought and creating an environment to allow the empowered learner to experience the thrill and autonomy of the effects of independent thought. This process promotes "intrinsic motivation" and involves "taking actions which affect impact, competence, meaningfulness and choice" (Van Aswegen, 1998:404). She suggests that empowerment takes place by promoting participation of individuals in their practice and their learning. She divides this process into two components: "(1) a cultural change process: this means defining new, or revising and reaffirming existing values; and (2) a paradigm shift: this means changing what an organization believes about itself and how it thinks and acts. There should be a move from organizational domination to person participation through the process of critical reflective practice thus, a partnership. The paradigm shift results in commitment, as the learners'/practitioners' actions are freely chosen, owned, and critiqued without any requirement to do so" (Van Aswegen, 1998:405).

This emancipatory learning is brought about by the educator creating space for students to engage in discourse and create their own meanings through personal experiences, with a view to transforming perspectives for better understanding (Van Aswegen, 1998; Schrieber \& Banister, 2002). This is coupled with my own struggle as educator, nurse, researcher and middle-class white South African woman trying to come to grips with understanding how my own identity (ies) surrounded by the multiple realities of the students with whom I work, within dimensions of shifting power relationships, affects my classroom practice. This notion that power is not static but moves fluidly, depending on situation and 
context is also a contention supported by Foucault (Janse van Rensburg, 2001:26).

Deep learning: Students who approach their learning with the intention of understanding, have been shown to lead to more sophisticated learning outcomes than surface approaches, which are associated with the absence of an intention to understand (Case \& Gunstone, 2001). Constructed knowing is the integration of the subjective and the procedural levels to arrive at a constructed knowledge stage which allows for thinking to occur in a very flexible and sophisticated way allowing the practitioner to speak, says Johns (2002:39) in an informed, passionate and assertive voice. Intuitive hunches are integrated with rational and complex thinking. Students understand that 'truth' or 'knowledge' is continuously 'under construction'. Knowledge becomes contextualised and students recognise themselves as creators of their own knowledge through their experiences, and that their understanding and knowledge gained is 'constructed' of and through these connected experiences. Constructed knowers integrate all parts of the self in knowing.

Critical thinking: Ennis (in Allison, 1997:59) defines critical thinking as "reasonable reflective thinking that is focused on deciding what to believe or do and on a purposeful mental activity that helps to formulate or solve problems, make decisions, or fulfill a desire to understand". Allison (1997:59) sees critical thinking as a framework into which complex cognitive processes such as problem solving, decision-making, critical thinking and creative thinking, all of which requires the use of multiple basic thinking skills, overlap and interrelates with each other. These include the higher order thinking of analysis, synthesis and evaluation as well as involving creative elements that permit the production of ideas and alternatives. Van Aswegen (1998:72) identifies the traits that mark the fair-minded critical thinker as intellectual humility, courage and perseverance, and "confidence in reason".

Critical reflective learning: This is the revised or new interpretation of the meaning of an experience that then forms a guide to further understanding and action. It involves analysis, interpretation, openness, "acceptance of self-reality, a change in personal meaning" and a review of previous values "in relation to the changed perspective" as well as potential implications. The key difference characterising critical reflective learning as opposed to other types of learning is that the issue is viewed in relation to the self (Van Aswegen, 1998:399).

\section{Operational definitions (the signposts)}

Reflective Journals: From 2000 to 2003, I was responsible for the introduction of reflective journals within a post-basic nursing programme in a South African educational department of nursing. Kerka (1996) identifies journal writing as a tool for adult learning. Their value in adult education is a means of expression, of "coming to voice", of developing the potential for critical reflective thought, and making meaning for nursing students (Paterson, 1995; Wallace, 1996; Marland, 1997; Van Aswegen, 1998).

Facilitator: As educator in this journaling process, I followed a student-centred Constructivist approach to teaching founded on the premise that, by reflecting on their experiences, students construct their own understanding of the world they live in (Abdal-Haqq, 1998). My role as educator is secondary and supportive in nature.

Critiquing: Feedback to students on diary entries can be problematic and the specific approach to feedback has been a focus on thought processes, rather than content. My intention was to guide, facilitate, validate and support the student rather than provide judgement. Efforts were made to maintain confidentiality and the trust of the student to promote freedom of expression.

\section{METHODOLOGY}

The travelogue: This paper is an account of a selected component of research within a larger study. It employs a qualitative, contextual, descriptive design using content analysis to identify categories and themes to illuminate the findings. It draws on elements of critical theory in that this study forms part of a larger participatory action research study aimed at enhancing critical, reflective practice. This multi-modal study draws on a multi-method approach, of which content analysis of students' self-evaluations of their reflective journals forms one of the methods.

The destination: The research question asked is: What are post-basic nursing students' perceptions of the 
value of journaling as a means of learning?

The map: Prior to engaging in the journaling assignment, nursing students were given instructions on the process of journaling and on the required structure of the journal, which comprised five elements: (1) a free-form stream-of-consciousness reflective component requiring reflections related to personal, health, health practice, educational or nursing discipline-related issues; (2) commentary and reflections on newspaper-generated articles reflecting health related issues; (3) analysis of journal articles, especially research-based journals and the relevancy to nursing practice; (4) self-evaluation of the journal; and (5) the critiquing process which explained the rules of conduct in dialogue taken by the facilitator in the role of critiquer.

Given the constraints of the health and educational system, the purpose of the reflective journals was to promote critical reflective thought and practice through:

- Engaging nursing students in a learning process on a continuous and regular basis, particularly in light of the limited student/ lecturer contact.

- Providing a forum for an awareness of current events as a macro context of a system that shapes their nursing practice.

- Encouraging academic literacy through writing practice in a psychologically safe environment.

- Self-directed learning.

\section{Participants (the travellers)}

The research group comprised post-basic nursing students who had completed reflective journals between the years 2000 and 2003 ( $\mathrm{N}=110)$. The nursing students' ages ranged from 24 to 58 ; the majority were black African women and the medium of instruction was English, the second language of the majority of the students. Ninety-eight percent of the nursing students were part-time students, working in various health care services ranging from deep rural to urban settings. The participants were mothers and wives, many with strong community commitments. One hundred and ten ( $\mathrm{N}=110)$ nursing students completed reflective journals between the years 2000 to 2003. The sampling included only those nursing students who had completed their journals and a self-evaluation commentary $(n=71)$ of their reflective journals. Informed consent was obtained from participants. Approval for the research was obtained from the institution's ethics committee.

\section{Data generation}

The sources of data were written self-evaluation commentaries by the students on the various components of their reflective journals. These were free-form openended self-evaluations that provided rich, contextual descriptions. The commentaries focused specifically on nursing students' perceptions of journaling as a learning tool for "deeper" learning. At journey's end, students were required to consider the criteria listed for critical reflective practice and provide their written perceptions of the value and limitations presented by the journal writing assignment after reviewing all their journal entries.

The reflective journals with the self-evaluation commentaries were collected at the end of each course. The commentaries were separated out for photocopying. Concepts reflecting the value and limitations of reflective journaling were highlighted and sorted, resulting in a set of categories as shown in Table One. When students wrote similar comments, they were placed under 'common findings'. The decision to use content analysis was appropriate as it "describes the process of organising and integrating narrative, qualitative information according to emerging themes and concepts" (Polit \& Hungler, 1997:454). Because the journal was broadly divided into three components, reflections, engagements with newspaper articles and engagements with journal articles, Table One reflects this division focusing on the perceived values or limitations of journaling related to these components. The table is further divided into sections on critical thinking and reflection, as the criteria for these learning components shape the students' evaluations. A further section 'General' comprised concepts that did not specifically refer themes on critical thinking, reflection, news or journal articles. As some students referred to techniques or resources supporting journaling, such as the Question Prompt, the criteria for self-evaluation or guided internet access, these too, were recognised as a category. These categories generated the following themes (see Table 2): journaling as a tool for learning; type of learning; effects of learning; difficulties associated with journaling; use of journaling and sustaining the process. 


\section{Measures to ensure trustworthiness}

The reflective journals yielded thick descriptions and so I was able to correlate written reflections within reflective journals with the self-evaluation commentaries and the facilitator's critique. In this way, I could corroborate or refute elements of the students' selfevaluation. Also, the commentaries themselves, reflected 'thick descriptions'. Other measures of trustworthiness included my own reflective journal, peer debriefing, prolonged engagement and persistent observation over four years, literature control by referring to similar studies, an audit trail and triangulation with other methods and data.

I tried to structure a psychologically safe environment for the students through written guidelines which guaranteed the students the freedom to write freely with the understanding that the reflections were their personal experiences and therefore, could not be judged by others, hence the self-evaluation.

\section{Limitations of the study}

Since the self-evaluations were intended as a means of establishing a grade for the nursing students, bias could be a factor, in that an erroneous perception of gaining a better grade might have influenced some of the nursing students' remarks in their reflective journals.

\section{FINDINGS}

This section is organised to reflect key categories of the nursing students' perceptions of the value of journaling to promote deeper learning. In some cases these perceptions have been paraphrased and in others the nursing students gave "voice" to their thoughts (see italics). In my interpretation of the students' voices, I found evidence of similar findings in the literature, but a number of their perceptions appeared to be unique. Table One shows the full range of the students' valuing of journaling as a means to deeper learning.

\section{Journaling as a tool for learning}

A number of nursing students found this experience both enjoyable $(n=17)$ and challenging $(n=19)$ and at least $(n=25)$ supported the journal as a means of learning and indicated that it should remain as part of the learning programme. There were many paths to a journey's end and perhaps it was because the journals were so open-ended and allowed nursing students wideranging choices of topic and approach, that the students appeared to gain different insights from the process.

\section{Type of learning}

\section{Active learning}

Kerka (1996) notes that journals can provide tangible evidence of mental processes, and students themselves recognised this occurrence. Post-basic nursing students perceived active learning to have taken place as they acknowledged their ability to think analytically and more objectively $(n=7)$, to integrate learning from other areas $(n=6)$, to challenge preconceptions $(n=7)$, and to differentiate between real and ideal practice $(n=4)$ although they saw that this took time and effort. Kok and Chabeli (2002:36) recognise that the interactions that forms the basis of reflective journaling, is in fact central to Outcomes Based Education where the focus "no longer falls on memorising factual knowledge, but on collaborative interaction to develop critical thinking skills...The emphasis falls on embedding quality problem-solving skills rather than on memorizing".

\section{Developmental learning (includes cogni- tive): $(n=18)$}

Learning was perceived to have occurred after prolonged engagement by the nursing students. "Whenever I did a diary entry, I wrote down what came to mind. Then as the year went by I began to think more deeply and wrote about what l'd spent some time thinking about."

A number of nursing students noted that the process was difficult, long and continuous: "During the first couple of months into the programme I was very irritated and could not understand why we had to do this assignment. I initially found no purpose in doing it and thought it was really a waste of time and energy. As the months went by I began to benefit from the diary in that I started to enjoy the reflective thought as it make me stop and relook at the way I handled situations and if I had the opportunity, what I would do to change my response. This is very evident when comparing my entries from the first couple of months to later months. I began to reflect, not only on issues that personally or emotionally affected me but also on day-to-day experi- 
Table 1: Summary of students' $(\mathrm{N}=71)$ perceptions of the value and limitations of journaling

\begin{tabular}{|c|c|c|}
\hline & Perceived value & Perceived value \\
\hline \multirow{4}{*}{ 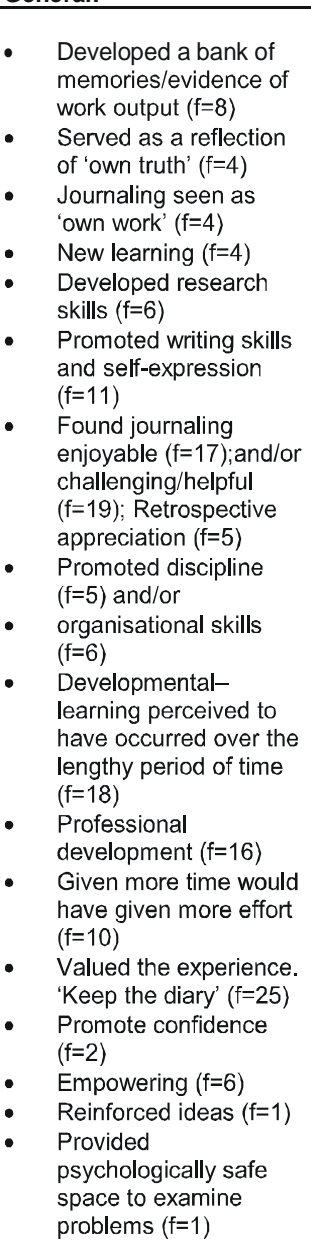 } & \multirow[t]{2}{*}{$\begin{array}{l}\text { Reflective thinking: } \\
\text { Reflective thinking enabled: } \\
\text { - } \\
\text { Altered/broadened perspectives }[18) \\
\text { Deeper understanding }(f=12) \\
\text { - } \quad \text { Valuing of introspection }(f=10) \\
\text { Development of self-insight }(f=13) \\
\text { Exploring of emotions }(f=9) \\
\text { - }\end{array}$} & 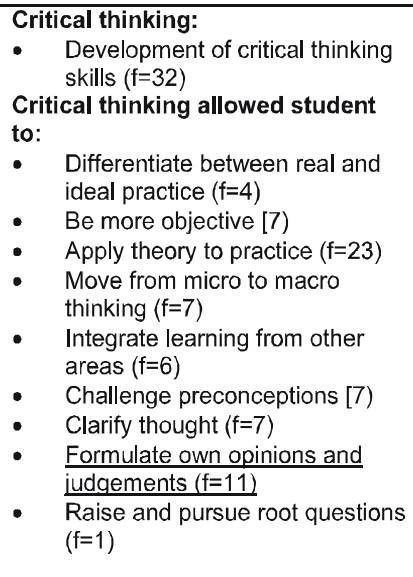 \\
\hline & & \multirow{2}{*}{$\begin{array}{ll}\text { Journal 'evidence based' section: } \\
\text { - } & \frac{\text { Source for research material }}{(\mathrm{f}=6)} \\
\text { - } & \text { Provided sources of current } \\
\text { health information }(f=14) \text { and } \\
\text { allowed students to keep } \\
\text { updated ( } f=40) \\
\text { - } \\
\text { Promoted new, frequent, in- } \\
\text { depth active reading }(f=26) \\
\text { - } \quad \text { Piqued curiosity }(f=3) \\
\text { Learned to read and analyse } \\
\text { critically }(f=6) \\
\text { Evaluated credibility of sources } \\
(f=6) \\
\text { - Students joined a new library } \\
(f=2)-\text { already members of } \\
\text { institutional library }\end{array}$} \\
\hline & $\begin{array}{l}\text { News article section } \\
\text { Served as a reference to society and } \\
\text { provide a context for health }(f=12) \\
\text { - Overview of health trends }(f=4) \\
\text { Served to highlight/explain issues } \\
\text { seen in own health service }(f=9) \\
\text { Provided a reality check on the } \\
\text { constraints within the health service } \\
(f=2) \\
\text { New behaviour - buys newspaper } \\
(f=3) \\
\text { Provided sources of current health } \\
\text { information }(f=11) \text { and allowed } \\
\text { students to keep updated }(f=6)\end{array}$ & \\
\hline & $\begin{array}{ll}\text { Facilitator feedback } \\
\text { - } \quad \text { Non-judgemental critique }(f=3) \\
\text { - } \quad \text { Support/clarification }(f=16) \\
\quad \text { Sharing of entries }(f=4)\end{array}$ & $\begin{array}{l}\text { Valued following guided supports: } \\
\text { - } \quad \text { Question prompt: }(\mathrm{f}=6) \\
\text { - } \quad \text { Guided } \\
\text { and journals: }(\mathrm{f}=6)\end{array}$ \\
\hline Perce & erc & Per \\
\hline Reflective writing & $\begin{array}{ll}\text { - } & \text { Uncertainty re expectations }(\mathrm{f}=12) \\
& \text { Insufficient instruction/explanation } \\
(\mathrm{f}=4) & \\
\text { - } & \text { Limited/delayed feedback }(\mathrm{f}=4) \\
& \text { Self-confidence affected }(\mathrm{f}=3) \\
\end{array}$ & $\begin{array}{rr}\text { Journal/ } n \\
\text { - } & \text { Avoid } \\
\text { irreles } \\
\text { - } \quad \text { Lack } \\
\text { news }\end{array}$ \\
\hline \multicolumn{3}{|c|}{$\begin{array}{l}\text { General. Difficulty in or with: } \\
\text { - } \quad \text { Critical thinking }(f=2) \\
\text { - } \quad \text { Maintaining motivation }(f=4) \text { as lacked confidence in own judgement }(f=7) \text { or unable to see relevance }(f=1) \\
\text { - } \quad \text { Length of involvement }(f=4) \\
\text { - } \quad \text { Time overload/number of entries }(f=18) \\
\text { - } \quad \text { Uncomfortable, conflicting emotions }(f=4) \\
\text { - } \quad \text { Merception of irrelevancy of assignment }(f=1) \text { initially }(f=2) \text { or inability to see as learning priority }(f=1) \\
\text { - } \quad \text { Writing articulately }(f=5) \\
\text { - } \quad \text { Completing assignment }(f=20) \\
\text { - } \quad \text { Reflecting and thinking at same level/rate continuously }(f=1) \\
\text { Self-evaluation }(f=3) \text { and }(f=35) \text { who did not attempt the free-form self-evaluation, but did complete the rubric }\end{array}$} \\
\hline
\end{tabular}

ences that we often don't think twice about. I have found that I was able to learn from my own experiences, and that I have grown professionally as a manager".
In general, nursing students visibly experienced the benefits of the prolonged engagement with their diary: "It made me not to walk with blind open eyes". 


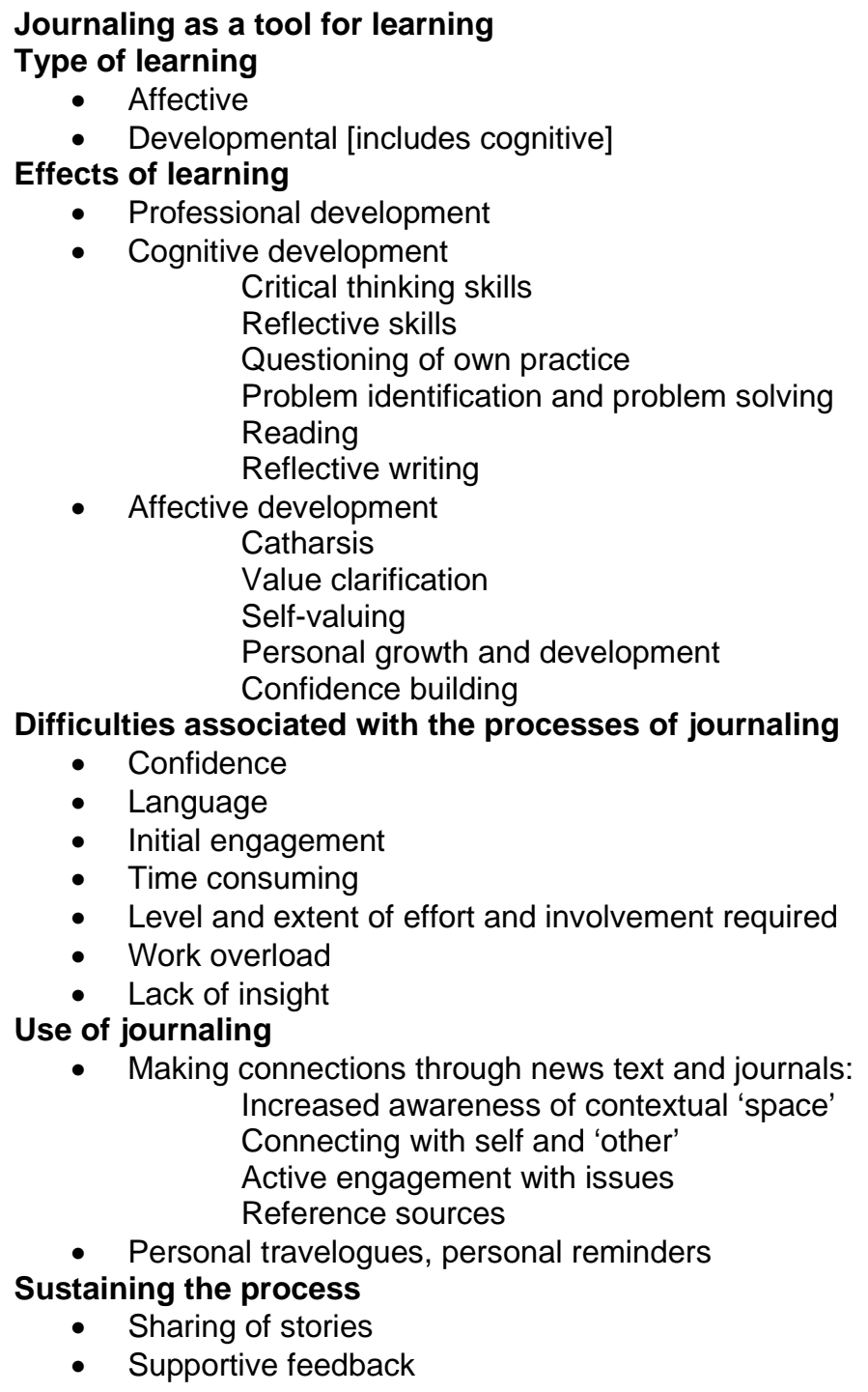

- Personal travelogues, personal reminders

Sustaining the process

- Sharing of stories

- Supportive feedback

\section{Effects of learning}

\section{Professional development $(n=16)$}

Reflecting on nursing practice and reading critically on health related issues promoted professional development in the nursing students. Interestingly, some students believed that the process of journaling promoted discipline $(n=4)$, improved their organisational skills $(n=5)$, and at least nine noted that if there had been more time available, the journey would have been worth the additional effort. Orem (1997) through the findings of his study suggests that "an effective application of journal writing can convince practitioners of their own innate ability to make meaning of their professional lives".

\section{Cognitive development}

- Development of critical thinking skills ( $\mathrm{n}=32$ ): One student noted: "I have used some of this process before but now was able to give it a name. I feel I am able to consider a wide variety of point of view, as I have always been interested in understanding where people are coming from, why and what makes them think the way they do. I have been able to grasp two varying points of view and observe how people speak past each other, not hearing what the other says...In the beginning I used the 
analytical question hand out to guide my writing. Towards the end of the year I was able to automatically analyse the situation I was writing about". Another makes the connection between critical thinking and reflection: "I have learned to implement these critical thinking techniques to assess, plan and evaluate situations in my work and home life. The more I reflect the more critical I become, and the more critical I am, the more reflecting I do". This process results in self-regulation and Kuiper (2004:195) notes the connection: "Successful self-regulation requires dependable experiential knowledge; use of metacognitive (that is reflective thinking) and cognitive (that is critical thinking) processes; and understanding of social and cultural influences on learning".

- Development of reflective skills $(n=18)$ : Journaling enabled post-basic nursing students to address issues at a deeper level, looking beyond the superficial aspects of the problem. One nursing student suggested it helped to develop patience and understanding of patient concerns through deeper reflection. Some nursing students noted that it became easier to find solutions to problems by making the implicit explicit. Many students appreciated the broadening of their perspectives $(n=18)$ and recognised reflection led to deeper understanding $(n=12)$, a valuing of introspection $(n=10)$ and the development of self-insight $(n=13)$ : "If I had written some of the entries as soon as they had happened, the diary entries would be very different and more emotive in response. With the delay in writing, I was more likely to be in control of my emotions and be more objective in my thoughts and ideas".

- Questioning of current practice $(n=7)$ : $R e-$ flecting provided an opportunity for nursing students to revisit their nursing practice. The students recognised their ability to view clients holistically, consciously using different perspectives and integrating new and diverse knowledge and make their own judgements $(n=11)$. Reflection allowed nursing students to "analyse issues pertaining to daily living and professional practice and form judgements and conclusions and to anticipate the actions of other professionals, patients and members of the community in diverse areas of living".

- Problem identification $(n=21)$ and problem solving ( $n=9)$ : Journaling allowed nursing students to describe and discuss their personal, workplace-related problems or those encountered in their studies. These same elements were identified by Paterson's 1995 study. Journaling enabled the students to address issues at a deeper level, looking beyond the superficial aspects of the problem. The questioning and comments of the facilitators appeared to help this process: "I enjoyed replying to the comments, as it made me think more deeply. Often it also made me see things differently. It broadened my vision as I was used to seeing things 'tunnel vision".

- Reading ( $n=26)$ : This section of the journal promoted new, frequent, and in-depth active reading: "I have got an interest in reading articles - something that used not to do. I have seen the aim of reading an article is not just to read for news, but now I am able to analyse whatever I read. I read an article with an open mind now". I am aware from personal observations in discussions with both students and staff that in general, students do not read newspapers or research journals. Pearcey (1995) established that up to 93 per cent of nurses do not possess the skills or confidence to locate and read research analytically.

- Reflective writing: Writing was seen as a means of self-expression by nursing students and journaling was seen to increase vocabulary and promoted the use of dictionaries and thesauruses $(n=11)$. Ten $(n=10)$ nursing students indicated how difficult it was to start writing and a number noted that they had put this off as long as possible. However, as one nursing student noted that once started, she was surprised at how much fun it was and how many interesting things she learned. "Hopefully this has taught me that not all things are as bad as they seem, once you get started and have the courage to see it through to the 
end'. As Cobine (1995) notes, students move "from self-expressive writers to expressively communicative writers".

\section{Affective development}

- Catharsis ( $n=9)$ : Journaling "made me feel lighter with my problems". According to Van Aswegen (1998) critical reflective practitioners are self-aware, which implies an understanding of the linkage between the cognitive and affective constituents of the self. Although only three nursing students named the exploration of emotions as a value, it was implicit in many of their examples. It was "very draining emotionally, especially some of the reflective thoughts. The process of writing thoughts down is exhausting, although it is a kind of 'therapy' too, and helps to clarify ones feelings. It was a safe forum to 'vent' and not fear reprisals". "Diaries taught me to come face to face with my feelings and my fears...they have taught me to deal with my emotions". The downside of this was that nursing students $(n=4)$ found some of the terrain too difficult to navigate, leaving them emotionally and mentally drained.

- Value clarification $(\mathbf{n}=5)$ : The reflective process "Helped me to transcend prejudice ...". It helped the student to "deal with my attitude in being judgemental without obtaining enough facts about the person or the matter at hand". Journaling "encouraged students to seek articles, read newspapers, reflect on emotions and viewpoints, to be aware of current affairs and political situations that could impact on their work, and to apply critical evaluation in their analysis". "It made one more conscious of others' beliefs and viewpoints, particularly within our South African society, and to understand the need for tolerance and sensitivity".

- Self-valuing ( $n=13)$ : The journals allowed for the recognition of personal worth and ability and achievement. Marland's (1997) own research made similar findings. Seven nursing students recognised their ability to think independently and form an opinion and so could choose their own routes. Four nursing students thought it was worth noting that journaling as a creative process, was their own work entirely. Journaling developed confidence, "I enjoyed doing them as I saw the benefits. I also felt more confident, realising and seeing that my point of view was never right or wrong, and that we all see things differently, and its OK".

- Personal growth and development ( $n=22)$ : A noteworthy number of students recognised the value of journaling towards their own personal growth. "I am a changed person". "It was a growing process". Kok and Chabeli (2002) corroborate this through their use of a focus group interview of six fourth-year nursing students who had engaged with reflective journals over a six-month period. They identified selfevaluation, intellectual growth and self-awareness resulting from the process of reflective journaling.

- Issues affecting confidence $(n=3)$ : A student aptly cited the philosopher George Bernados: "In thinking, if a person begins with uncertainties, they shall end in doubts, but if they can begin with doubts, they will end in certainties". Some nursing students actively engaged in reflection, whether or not feedback was given, although disappointment was registered if there was no feedback. A few nursing students noted that journaling was difficult because it was new to them: "Didn't know if we were right or wrong till we were marked." In the early stages a number of nursing students noted an initial lack of understanding of the requirements. The process of understanding how to journal appeared to take time, a point also noted by Paterson (1995): "Initially the Journal/Diary appeared to be a lot of unnecessary work. We were loaded with work at the beginning of the year and the burden of keeping a diary seemed impossible. Towards the latter part of the year keeping a diary became very interesting. Reflecting on various incidents and situations enabled me to see various aspects from different perspectives". Orem (1997) argues that for many adult learners, journaling is a positive reinforcement of the learning process and that those students, who are comfortable with the medium, appear to demonstrate more in-depth learning. 


\section{Difficulties associated with the processes of journaling}

\section{Language difficulties $(n=5)$}

Some nursing students experienced difficulty in writing articulately. Some first- and second-language nursing students' critical reflective thoughts were hampered by their lack of familiarity with the art and process of writing in the English language and understanding its nuances: "I lack precision and often give insufficient details, which impacts on the evaluators ability to interpret my statements ...". The recognition of these barriers, however, encourages the traveller to find translators: "My lack of command of the English language can be frustrating and impacts on my communication ability, however this course has encouraged me to use the dictionary and thesaurus".

\section{Initial engagement $(n=20)$}

Starting seemed for many, to be the hardest part of the journey. Kok and Chabeli (2002) recognise this as occurring in their own study as a result of lack of clarity on the purpose, goals and expectations connected to journaling. Early understanding of the process of critical reflection allowed for early engagement. The later the engagement, the more difficult the nursing students found it to commit to the process of journaling. It seemed that those nursing students, who had difficulty in engaging, tended to withdraw from the process and had difficulty completing the assignment $(\mathrm{n}=7)$ : "In the beginning, I was lost with diaries.... I delayed to send these entries and also there was a delay in receiving comments". Paterson (1995) made concurrent findings, but also noted other reactions of anger and frustration at the process. However, other students, while slow in starting, with understanding and support, engaged effectively: "I took a while to get going as I am no writer, but once I got started I thoroughly enjoyed myself".

\section{Time-consuming $(n=21)$}

For many nursing students however, the journey was too time-consuming, requiring much effort in terms of reading, reflecting, analysing, and writing: "I had to read many articles in order to come up with one that was appropriate". It takes "some effort to continuously think of how one reacts to experiences at work and to record the information and then reflect on how it impacts on one's nursing care. The purpose of analysing our care and using reflection, has value. However, it is difficult to consciously analyse one's reasoning or logic, record it in writing, reflect on how to apply it meaningfully to be of any meaningful significance".

Maintenance of motivation and effort was difficult. Journals "need a lot of time and a lot of thinking which was too much for me". This is in line with findings by Kok and Chabeli (2002) and Paterson (1995:211) who also identified common resultant problems of "procrastination, superficial, non-reflective entries; waning enthusiasm about the activity; and unwillingness or inability to reflect".

\section{Level and extent of effort and involvement required}

Journaling was seen by some as an unpleasant experience because of effort, but this was counterbalanced by the realisation of the resultant development of the individual and the professional person. Nursing students recognised where they had failed to meet the specified requirements. Some students explained that their learning programme was very demanding and had not prioritised the journal assignment. This led to the postponing of the writing, which then became perceived as a psychological as well as physical burden. Difficulty was identified in writing articulately $(n=5)$; the length of involvement $(n=4)$ and reflecting and thinking at the same level and rate continuously $(\mathrm{n}=1)$ : "I am really tired and have had so much work to do, and so instead of writing, here are pictures of where I work and the people with whom I work". Paterson (1995) noted the varying levels of reflective ability of students. Nursing students experienced difficulty in critical thinking $(n=2)$, completing the assignment $(n=7)$, and maintaining motivation in writing $(n=4)$ as they lacked confidence in their own judgement $(n=7)$.

\section{Work overload $(n=18)$}

Heartfelt expressions of concern by the nursing students on the number of entries required ensued: "The diaries were difficult to do because of the workload we had since we are not really full time students. We are expected to do our school work perfectly. To be a good parent, to be a cook at home and be a good/excellent wife and to be excellent at your workplace. I found it difficult to do it".

\section{Lack of insight $(n=7)$}

Some recalcitrant travellers completed their self-evalu- 
ation without much insight. It appeared that the sum of the journey did not add up to the whole. Three nursing students observed that the self-evaluation was difficult and uncomfortable.

\section{Use of journaling}

\section{Making connections through news text and journals}

- Increased awareness of contextual 'space' ( $n=12)$ : Many nursing students noted their reading of current issues in newspapers and journals in the land of their travels had widened their awareness of current events and provided an appreciation of broader contexts for their nursing practice.

- Connecting with self and 'other' $(n=12)$ : Familiarity with the terrain and local inhabitants makes for smoother travel. Nursing students developed an understanding of the clients in the community through news articles that reproduced clients' concerns and complaints, as well as their appreciation of elements in the health-care system. The news articles throw a different light on nursing practice in general, from which the nursing students can extract common truths. They "serve as a good reference to society". Students perceived value in being able to observe the changes happening "on health matters, changes in people and the way this country is governed."

- Active engagement with issues: Many nursing students started to read and view newspapers in a different light. They saw reading newspaper articles as a basis for discussion and argument, and engaged the journal as a sounding board. The assignment forced nursing students to reflect with understanding and reading became an active process as students used analytical questions to identify, understand and see relevance of issues. Nursing students $(n=11)$ noted a development of a broader knowledge of current issues.

- Reference sources: Curiosity was piqued and some nursing students $(n=3)$ made a point of verifying information at the source. Journal articles formed wells for reference material for nursing students practice $(n=40)$ : "This kind of exercise will help us next year when doing our research. We shall have an idea of how to look or search for information".

\section{Personal travelogues, personal reminders $(n=8)$}

The recording of events and developments of the journey may never be precise when there is a reliance on memory. Journals make remembered facts meaningful to the traveller: "I am now able to look back and see that I have come a long way." Another recognises " $A$ feeling for where one has come from and where one is going". A student observed nostalgically: "They brought back a few sad memories and some very happy ones. One forgets so quickly as life just goes on". The stories within the journals may provide valuable insights, suggested one nursing student. As a historical record, reflective journals "provide the springboard. Not only through its accuracy in terms of time, date and year but also by the mere fact that it is one's sole possession. No one can take it from you. You are at liberty to hand it from generation to generation". Marland (1997) identified parallel conclusions to these nursing students.

\section{Sustaining the process}

\section{Sharing of stories $(n=4)$}

The sharing of journal entries encouraged some nursing students to continue the journey: "Diary entries were read out in class, for this I'm grateful as it gave me ideas of what's expected of me".

\section{Supportive feedback}

Increasing levels of reflection and critical thinking are evidenced when feedback is immediate, frequent and recognition is given. This study indicated that journaling was a new skill for some $(n=6)$ and that a number of nursing students had difficulty in engaging in journaling $(n=10)$. Some nursing students $(n=4)$ apparently felt there was insufficient explanation of the process and limited or delayed feedback $(n=4)$ that affected their writing. This appeared to affect levels of self-confidence $(n=7)$ and motivation $(n=4)$ and these nursing students therefore did not appear to trust their own judgement or the value of their own work. Higgins (2000) therefore argues that the process of feedback is a complex interweaving of emotion, identity, power dynamics and competing discourses and so must be approached with care. This is evident in the following student's remarks: "It was difficult to start the process of writing for 'fear' 
of writing the wrong thing. Once the first entry was written and returned with comments, it was easier to see what the process was all about. Trying to move away from a right or wrong answer takes some getting used to. Upbringing/educational norms instil a sense needing to write the precise information the educator is looking for. In this assignment there were no hard and fast rules, other than the reflection and critical thinking exercises. Even at the beginning I was concerned that there was always a comment/question and wondered if I would ever 'get it right'. I then came to the understanding that there is no right or wrong answer".

Cobine (1995) suggests that engaging in written dialogue with students provides them with an audience to "thereby enhance their rhetorical awareness".

\section{CONCLUSION}

Is journaling empowering? Journaling, as a reflective learning medium, particularly in circumstances where there is a limited student/facilitator contact, does appear to enable engagement in reflection and learning for a prolonged and continuous period of time. However, the levels of engagement and the learning derived from the process seem to vary and journaling does not appear to be an exercise to be entered into lightly.

This paper describes journeys shaping learning: mine, as an educator and researcher, reflecting on the process of learning as seen through the pens and journals of students, and the students, who through their stories, found voice to their journey of self-discovery.

These parallel journeys were undertaken to improve our practice. Living in a country where democracy is highly prized and which has arrived after centuries of struggle, I cannot but appreciate that this gift is not easily claimed. Powerlessness has and still does exist at all levels and nursing is no exception. If I can learn to tread softly, carefully, mindfully and learn to understand the students I work with and the contexts that they work within through their journals. If I can help create a space to allow nurses to reflect on their profession with understanding - but more importantly, to take action and move beyond the limitations created by and for the autopilot nurse. If I can, through introducing the reflective journal, support the students as managers of their own destinies and the choosers of their own paths, I too, perhaps will have some understanding of my role as the 'transformatory educator' in Van Aswegen's model which should help both student and I from reproducing the dominant ways of knowing nursing with which we currently struggle.

\section{RECOMMENDATIONS}

Journaling is a useful tool for formative, developmental learning. The recommendations derive from the difficulties experienced by students in engaging in the process:

- Paterson (1995:214) urges sensitive management of students by the educator in terms of recognition and support of differences. She suggests a type of scaffolding approach, intuiting the balance between providing support and information when needed, but withholding information and "nudging" the student from engrained patterns of thinking to considering alternative forms of thinking. Journaling is not an easy process and requires time, effort and commitment and an appreciation that reflection is in fact, a developmental process.

- The orientation to critical reflective journaling should be comprehensive and Paterson (1995) indicates that early engagement is dependent on an appropriate orientation.

- Ongoing focus and facilitation of critical reflective writing should be maintained. Kerka (1996:3) suggests that the key lies in the "proficiency in reflection".

- Feedback or "critiquing" should be a regular, ongoing, immediate, non-judgemental, supportive process.

- Student journal entries should be shared and discussed with their peers,

- Student workload and commitments should be considered and the required effort could be negotiated with the students.

\section{REFERENCES}

ABDAL-HAQQ, I 1998: Constructivism in teacher education: Considerations for those who would link practice to theory. ERIC Digest. Available at: http://www.ericfacility.net/ericdigests/index/ Accessed: 20 April 2002.

ALLISON, M 1997: Fostering critical thinking in nurse education: The development of a measuring tool. (In: Thomson, S Ed. 1997: Nurse Teachers as researchers. A reflective approach. London: 
Arnold Publishers).

CARR, W \& KEMMIS, S 1986: Becoming critical: Education, knowledge and action research. Lewes: Falmer.

CASE, J \& GUNSTONE, R 2001: "No time to think" - Interactions between students' perceptions of time and approaches to learning. Paper presented at the Higher Education Close Up Conference 2. Lancaster University, 16-18 July 2001.

CHABELI, M 2002: Portfolio assessment and evaluation: Implications and guidelines for clinical nursing education. Curationis, 25(3):4-9.

CHAPMAN, L \& HOWKINS, E 2003: Work-based learning: Making a difference in practice. Nursing Standard, 17(34) (In: Proquest Information and Learning Company (2004):39 Website. http:// gateway.proquest.com/openurl?url_ver=Z39.88- 29 September, 2004).

COBINE, GR 1995: Effective use of student journal writing. ERIC Digest. Available at: http://www.ericfacility.net/ericdigests/index/ Accessed: 20 April 2002.

ELLSWORTH, E 1992: Why doesn't this feel empowering? Working through the repressive myths of critical pedagogy. (In: Luke, C and Gore, J eds. Feminisms and Critical Pedagogy. New York: Routledge).

ENNIS R 1987: A taxonomy of critical thinking dispositions and abilities. (In: Thompson, S ed. Nurse teachers as researchers. A reflective approach. London: Arnold Publishers.)

GWELE, NS 2003: Globalization and the nursing workforce: The importance of what we care about. Paper presented at the occasion of her inauguration as a professor of Nursing. University of Natal: Durban. 16 September 2003

HIGGINS, R 2000: Be more critical: Rethinking assessment feedback. British Educational Research Association Conference. Cardiff University. September 7-10.

JANSE VAN RENSBURG, E 2001: An orientation to research. Rhodes University, Environmental Education Unit, Research methods short course. Grahamstown: Environmental Education Unit, Rhodes University.

JOHNS, C 2002: Guided reflection. Advancing practice. Oxford: Blackwell Science.

KERKA, S 1996: Journal writing and adult learning. ERIC Digest \#174. Available at: http://www.ericfacility.net/ericdigests/ Accessed on: 25 May 2003.

KOK, J \& CHABELI, M 2002: Reflective journal writing: How it promotes reflective thinking in clinical nursing education: A students' perspective. Curationis, 25(3):35-42. In: Higher Education Close Up Conference 2. Lancaster University. 16-18 July. KUIPER, RE 2004: Nursing reflections from journaling during a perioperative internship. Association of Operating Room Nurses. AORN Journal, 79(1):195-218.

KUOKKANEN, L \& LEINO-KILPI, H 2000: Power and empowerment in nursing: Three theoretical approaches. Journal of Advanced
Nursing, 31(1):235-241.

LEHMANN, U \& SANDERS, D 2002: Human Resource Development. South African Health Review. Available at: http:// www.hst.org.za/sahr/2002/. Accessed on: 30 August 2003. MARLAND, G 1997: The reflective diary: An aid to practicebased learning. Nursing Standard, 12(13-15):49-52. NKOPODI, N 2002: Competition in higher education: Lessons from the corporate world. South African Journal of Higher Education, 16(1):74-81.

NORRIS, BD 2001: Transformation, diversity and organisational change within institutions of higher education. South African Journal of Education, 21(4):219-222.

OREM, RA 1997: Journal writing as a form of professional development. Midwest Research-to-Practice Conference in Adult, Continuing and Community Education Conference. Michigan State University, East Lansing, Michigan. Available at: http:// www.anrecs.msu.edu/research/accepted.htm. Accessed on: 20 August 2001.

OWENS, J; FRANCIS, D \& TOLLEFSON, J 1998: Conversations as a methodological tool. AARE (Australian Association for Research in Education) 1998 Conference. Available at: http:// www.aare.edu.au/contents.htm. Accessed on: May 272003.

PATERSON, BL 1995: Developing and maintaining reflections in clinical journals. Nursing Education Today, 15(3):211-220. PEARCEY, P 1995: Achieving research based practice. Journal of Advanced Nursing, 22(1):33-39.

POLIT, DF \& HUNGLER, B 1997: Essentials of nursing research. Methods, appraisal and utilization. Lippincott: Philadelphia.

RADEBE, G 2001: Policy in progress: Nurse training for the District Health System. HST Update, 54:5-6.

SCHRIEBER, R \& BANISTER, E 2002: Challenges of teaching in an emancipatory classroom. Journal of Nursing Education, 41(1):41-45.

VAN ASWEGEN, E 1998: Critical reflective practice: Conceptual exploration and model construction. Pretoria: Medunsa. (Unpublished PhD Thesis).

WALLACE, D 1996: Using reflective diaries to assess students. Nursing Standard, 10(36):44-47. 